\title{
Plants or bacteria? 130 years of mixed imprints in Lake Baldegg sediments (Switzerland), as revealed by compound-specific isotope analysis (CSIA) and biomarker analysis
}

\author{
Marlène Lavrieux ${ }^{1}$, Axel Birkholz ${ }^{1}$, Katrin Meusburger ${ }^{1,2}$, Guido L. B. Wiesenberg ${ }^{3}$, Adrian Gilli ${ }^{4}$, \\ Christian Stamm $^{5}$, and Christine Alewell ${ }^{1}$ \\ ${ }^{1}$ Environmental Geosciences, Department Environmental Sciences, University of Basel, Basel, Switzerland \\ ${ }^{2}$ Swiss Federal Institute for Forest, Snow and Landscape Research, Birmensdorf, Switzerland \\ ${ }^{3}$ University of Zurich, Department of Geography, Zurich, Switzerland \\ ${ }^{4}$ Geological Institute, ETH Zurich, Zurich, Switzerland \\ ${ }^{5}$ Eawag, Swiss Federal Institute of Aquatic Science and Technology, Dübendorf, Switzerland
}

Correspondence: Axel Birkholz (axel.birkholz@unibas.ch)

Received: 14 June 2018 - Discussion started: 19 July 2018

Revised: 6 April 2019 - Accepted: 26 April 2019 - Published: 22 May 2019

\begin{abstract}
Soil erosion and associated sediment transfer are among the major causes of aquatic ecosystem and surface water quality impairment. Through land use and agricultural practices, human activities modify the soil erosive risk and the catchment connectivity, becoming a key factor of sediment dynamics. Hence, restoration and management plans of water bodies can only be efficient if the sediment sources and the proportion attributable to different land uses are identified. According to this aim, we applied two approaches, namely compound-specific isotope analysis (CSIA) of longchain fatty acids (FAs) and triterpenoid biomarker analysis, to a eutrophic lake, Lake Baldegg, and its agriculturally used catchment (Switzerland). Soils reflecting the five main land uses of the catchment (arable lands, temporary and permanent grasslands, mixed forests, orchards) were subjected to CSIA. The compound-specific stable isotope $\delta^{13} \mathrm{C}$ signatures clearly discriminate between potential grasslands (permanent and temporary) and forest sources. Signatures of agricultural land and orchards fall in between. The soil signal was compared to the isotopic signature of a lake sediment sequence covering ca. 130 years (before 1885 to 2009). The recent lake samples (1940 to 2009, with the exception of 1964 to 1972) fall into the soil isotopic signature polygon and indicate an important contribution of the forests, which might be explained by (1) the location of the forests on steep slopes, resulting in a higher connectivity of the forests to the lake, and/or (2) potential direct inputs of trees and shrubs growing
\end{abstract}

along the rivers feeding the lake and around the lake. However, the lake sediment samples older than 1940 lie outside the source soils' polygon, as a result of FA contribution from a not yet identified source, most likely produced by an in situ aquatic source, either algae, bacteria or other microorganisms or an ex-site historic source from wetland soils and plants (e.g. Sphagnum species). Despite the overprint of the yet unknown source on the historic isotopic signal of the lake sediments, land use and catchment history are clearly reflected in the CSIA results, with isotopic shifts being synchronous with changes in the catchment, land use and eutrophication history. The investigated highly specific biomarkers were not detected in the lake sediment, even though they were present in the soils. However, two trimethyltetrahydrochrysenes (TTHCs), natural diagenetic products of pentacyclic triterpenoids, were found in the lake sediments. Their origin is attributed to the in situ microbial degradation of some of the triterpenoids. While the need to apportion sediment sources is especially crucial in eutrophic systems, our study stresses the importance of exercising caution with CSIA and triterpenoid biomarkers in such environments, where the active metabolism of bacteria might mask the original terrestrial isotopic signals. 


\section{Introduction}

While it is known that pollutant inputs have a severe impact on aquatic ecosystems, especially in agriculturally used catchments (Malaj et al., 2014; Allan, 2004; Liess et al., 2001), the influence of sediment input and sediment dynamics on biological quality and recovery of rivers remains highly uncertain (Scheurer et al., 2009; Matthaei et al., 2010). Sediment loads to freshwaters are increasing worldwide, often related to anthropogenic activities (Scheurer et al., 2009). Sediment pollution has been identified as one of the most relevant pressures to water bodies (Borja et al., 2006), and sediments are among the top 10 causes of biological impairment in freshwater ecosystems (US EPA, 2009). Land uses and agricultural practices modify the soils' erosive risk and the catchments' sedimentary connectivity, becoming a key factor of sediment dynamics and aquatic ecosystems' health. Restoration and management plans of water bodies can only be efficient if the sediment sources and their respective contributions, i.e. the proportion attributable to different land uses, are identified (Wasson et al., 2010; Sundermann et al., 2013).

The compound-specific isotope analysis (CSIA) technique, based on the compound-specific stable isotope signatures of inherent organic biomarkers in the soil, was developed and applied to discriminate and apportion the source soil contribution from different land uses (Gibbs, 2008; Blake et al., 2012; Hancock and Revill, 2013; Alewell et al., 2016). As the fatty acids (FAs) are transferable from plants to soils, stable and persistent in soils, mobile with sediments during flow events and easily isolatable from the other compounds in lipid mixtures, they are especially well suited for CSIA (Reiffarth et al., 2016). While FAs' assemblages are not variable enough among plant species to discriminate them, their $\delta^{13} \mathrm{C}$ signature differs among groups of plant species (Tolosa et al., 2013). The $\delta^{13} \mathrm{C}$ signature of biomarkers is assumed to be more preserved than their concentration during degradation and transport processes (e.g. Marseille et al., 1999; Gibbs, 2008), allowing sources to be discriminated in various studies in lake sediment and catchment studies (e.g. Galy et al., 2011; Fang et al., 2014), even dominated by $\mathrm{C}_{3}$ vegetation only (Alewell et al., 2016).

In addition to the CSIA, attention was given to some cyclic compounds as specific tracers for source identification. A large part of the cyclic compounds is synthesized by more restricted plant groups than linear alkyl lipids. Among the cyclic compounds, some triterpenes were validated as family- or even species-specific (e.g. some triterpenyl acetates for Asteraceae, some sesqui-, di- and triterpenoids for conifers, methoxyserratenes for Pinaceae; Lavrieux et al., 2011; Otto and Wilde, 2001; Le Milbeau et al., 2013; respectively). Mostly developed and successfully used for palaeoenvironmental studies (e.g. Jacob et al., 2008; Lavrieux, 2011; Guillemot et al., 2017), the high potential of these highly specific biomarkers (HSBs) for tracking sediment sources and evaluating the soil vulnerability remains underexploited.

The need to precisely identify sediment sources is especially important in eutrophic systems to enable efficient and targeted restoration measures. For this reason, we chose to use a mixed CSIA and HSB approach in the Lake Baldegg catchment (central Switzerland). Lake Baldegg, which is eutrophic, is a typical but also extreme example of a European freshwater body, as it suffered substantially from nutrient input (mainly phosphorus, P) during the second half of the 20th century. Studies have been carried out on the P source attribution into the lake, but the origin of sediments remains unclear. While the eutrophication history of Lake Baldegg has been extensively studied (e.g. Niessen and Sturm, 1987; Lotter et al., 1997; Lotter, 1998; Teranes and Bernasconi, 2005), an in-depth comparison of the lake evolution with the recent history of the catchment (including land use and agricultural practice changes) has not yet been performed.

Our project aimed at filling these gaps. In this paper, the soil isotopic signatures of FAs characterizing the main land uses of the Lake Baldegg catchment are quantified and compared to the evolution of the CSIA imprint of a 130-yearlong lake sediment sequence. This study is, to the best of our knowledge, the first sediment fingerprinting CSIA concerning a lake sediment core covering more than a century.

\section{Study site}

Lake Baldegg $\left(47^{\circ} 12^{\prime} 0^{\prime \prime} \mathrm{N}, 8^{\circ} 15^{\prime} 40^{\prime \prime} \mathrm{E}\right.$; $463 \mathrm{~m}$ a.s.l. $)$ is a eutrophic lake of glacial origin located on the central Swiss Plateau (Fig. 1). It has a maximum depth of $66 \mathrm{~m}$, a surface area of $5.2 \mathrm{~km}^{2}$ and a water volume of $0.173 \mathrm{~km}^{3}$. The lake is fed by 15 streams and has a mean residence time of 4.3 years (Wehrli et al., 1997). The outflow is located at its northern end. Its north-south catchment, having an area of $67.8 \mathrm{~km}^{2}$, has hillslopes of 700 to $800 \mathrm{~m}$ a.s.l. elevation. The catchment today is intensively used for agriculture: $77 \%$ is used as agricultural land, $12 \%$ as forest (mostly on the slopes) and $5 \%$ as urbanized areas (Wehrli et al., 1997). In 2015, one-third of the agricultural land was devoted to permanent grassland, $40 \%$ to cereals and arable lands (including $10 \%$ of maize) and $24 \%$ to temporary grasslands, while fruit production (small trees, mainly apples and pears) covered ca. $1 \%$ of the agricultural land (Federal Statistical Office, 2015). Intensive chicken farming and pig breeding are other important farming activities.

Previous studies have provided extensive information about the lake eutrophication history (e.g. Lotter et al., 1997; Lotter, 1998; Wehrli et al., 1997). Briefly, this eutrophication, starting in 1885 , translated into annually laminated (varved) sediments in a context of a constant anoxic lake bottom until the 1980s (anoxia below $60 \mathrm{~m}$ depth between 1885 and 1940, below $40 \mathrm{~m}$ between 1940 and 1970 , below $10 \mathrm{~m}$ between 1970 and 1982; Niessen and Sturm, 1987; Lotter et al., 1997). 


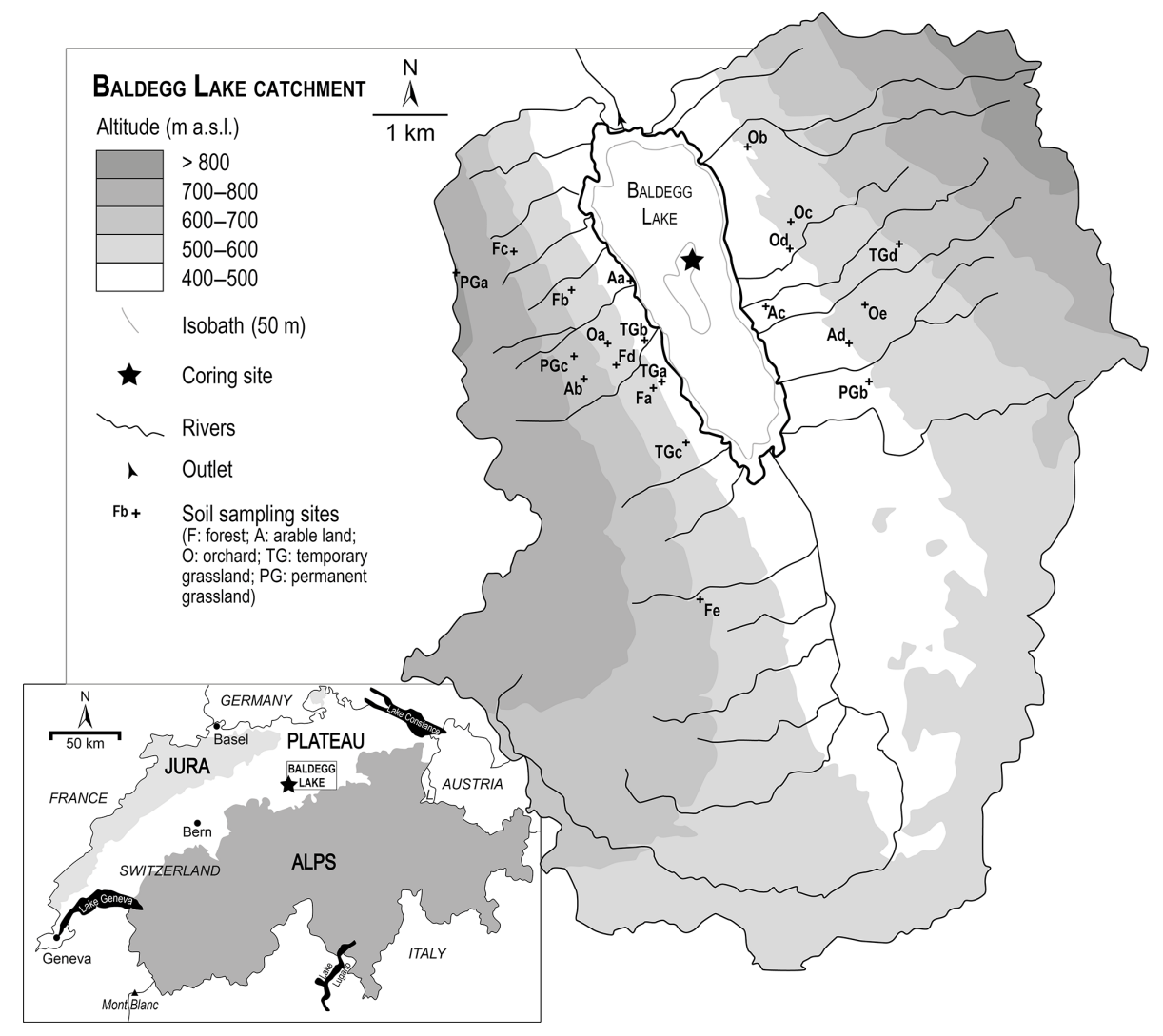

Figure 1. Catchment of Lake Baldegg with sampling sites.

Through the 20th century, a severe increase in phosphorus loads, stemming from the intensification of land use, population and industrial activities, has supported an increase in the eutrophication. The almost exponentially increasing phosphorus concentration in the lake water (up to $>500 \mu \mathrm{g} \mathrm{L}^{-1}$; Wehrli et al., 1997), leading to hypereutrophic conditions with dramatic fish kills and algal blooms, was curbed after the introduction of wastewater treatment plants and several restoration efforts. The introduction of an artificial oxygenation system into the lake water column in 1982 (Stadelmann et al., 2002) led to the disappearance of the varves from 1995. Despite the accompanying strong decrease of $\mathrm{P}$ concentrations in the lake to below $30 \mu \mathrm{g} \mathrm{L}^{-1}$ as the result of lake external and internal measures, the lake has not yet fully recovered from eutrophication (Müller et al., 2014).

\section{Materials and methods}

\subsection{Connectivity index}

With the purpose of sampling the source soils most likely contributing to the recovered lake sediment, a connectivity index model and a connectivity map were built. Connectivity patterns in the catchment were identified using a modified sediment connectivity index (IC) based on the ap- proach by Borselli et al. (2008) and modified by Cavalli et al. (2013) (Fig. 2). This index, calculating surface roughness from a high-resolution digital elevation model $(2 \mathrm{~m}$ resolution, swissALTI3D), indicates the degree of linkage controlling sediment fluxes throughout the landscape and, in particular, between sediment sources and downstream areas and finally the freshwater system.

\subsection{Sampling}

\subsubsection{Soils}

Soil sampling locations were chosen according to the abovementioned connectivity model approach, the land-use map (Fig. 2) and aerial photographs. The focus of this study was set on areas with high connectivity. Soil samples representing each main land-use type (arable lands, permanent grasslands, temporary grasslands, mixed forests, orchards) were taken. Five sites were selected for orchards and forests, four sites for arable lands and temporary grasslands and three sites for permanent grasslands. Within each site, four soil cores were sampled and mixed into a composite sample. For all forest sites the humus layer was removed prior to sampling. At four of five investigated forest sites no Oa layer was present (only partly degraded material, Oe, and intact plant material, Oi). Only at one site (Norwegian spruce and Thuidium 
(a)

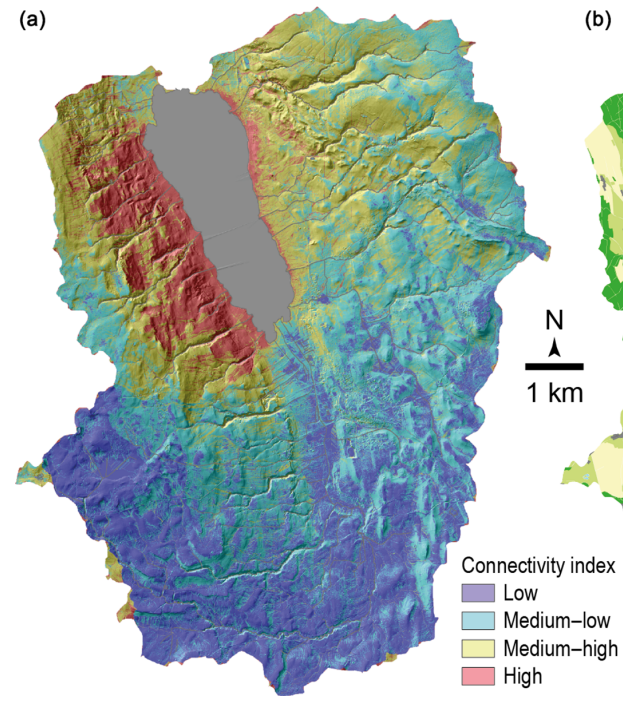

(b)

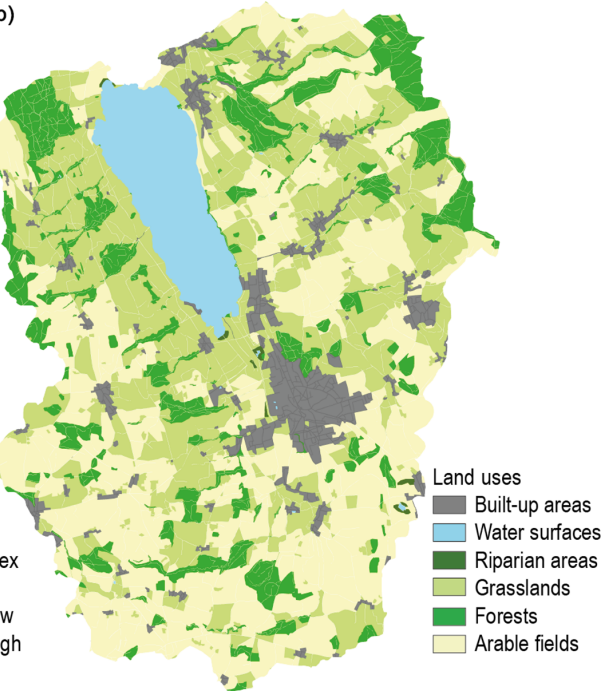

Figure 2. (a) Connectivity index for the Lake Baldegg catchment, underlain by a topographic map. The lake is indicated in grey. (b) Land-use map.

tamariscinum moss) had an Oa layer built up. For the orchards, samples were taken at the base of the trees, where no herbaceous vegetation was growing. Distinction between temporary and permanent grasslands was made from the vegetation diversity observed on the field, and the presence of a tilled horizon was checked with a Pürckhauer auger system. The uppermost $5 \mathrm{~cm}$ of the soil was sampled with a $5 \mathrm{~cm}$ high cylindrical steel ring $\left(98.2 \mathrm{~cm}^{3}\right)$ and stored in aluminium foil in the fridge until drying.

\subsubsection{Lake sediment core}

We subsampled a sediment core (Ba-09-03) in January 2016 retrieved in autumn 2009 in the deepest part of Lake Baldegg, which had been stored in a refrigerated storage room since then. The varved sediment allows the cores at a seasonal resolution to be dated back to $1885 \mathrm{CE}$. Detailed retrieving and sediment core information, as well as the age-depth model, is documented in van Raden (2012) and Kind (2012). The upper $45 \mathrm{~cm}$ of the core, covering the last 130 years, was sampled in 3-year slices. The turbidite of $1956 \mathrm{CE}, 9 \mathrm{~mm}$ thick, was sampled separately. Every second sample between 1885 and 2009 CE, as well as one sample older than $1885 \mathrm{CE}$, i.e. before the start of eutrophication, were further analysed. The oldest sample was dated to ca. $1870 \mathrm{CE}$ by extrapolating the sedimentation rate of the well-dated last 19th century varved part.

\subsection{Sample preparation}

After freeze-drying (lake sediments) or oven-drying (soils; $40^{\circ} \mathrm{C}, 72 \mathrm{~h}$ ), the sediment samples were carefully crushed with a pestle and mortar. Soils were dry-sieved at $2 \mathrm{~mm}$, which was not necessary for the fine-grained lake sed- iment. With great care the macroscopic elements (vegetal remains, stones) were hand-picked from all the samples. A total of 2 to $4 \mathrm{~g}$ of samples (soils and lake sediments) was processed for lipid extraction, using a mixture of $\mathrm{CH}_{2} \mathrm{Cl}_{2}: \mathrm{MeOH}(9: 1 v / v)$ in an Accelerated Solvent Extractor (Dionex ASE 200 for the lake sediments, Dionex ASE 350 for the soils). Lipid extracts were subsequently separated into neutral, acidic and polar fractions using solid-phase extraction on aminopropyl-bonded silica as described in Jacob et al. (2005).

\subsubsection{Fatty acid preparation for CSIA}

The acidic fraction, including the free FAs, was methylated at $60{ }^{\circ} \mathrm{C}$ for $1 \mathrm{~h}$ using $1 \mathrm{~mL}$ of $12 \%-14 \% \mathrm{BF}_{3}$ in $\mathrm{MeOH}$. Fatty acid methyl esters (FAMEs) were extracted from the solution by agitating it four times with ca. $2 \mathrm{~mL}$ hexane in the presence of $1 \mathrm{~mL}$ of $0.1 \mathrm{M} \mathrm{KCl}$. The final extract was stored in the freezer until analysis.

The purity of the extract and the concentration of the FAMEs were checked using a Trace Ultra gas chromatograph (GC) with a flame ionization detector (FID; Thermo Scientific, Walthalm, MA 02451, USA), as described in Alewell et al. (2016). Lake sediments' FAMEs' stable carbon isotopic composition was measured as described in Alewell et al. (2016) using a Trace Ultra GC, coupled via combustion interface GC Isolink and Conflo IV with a Delta V Advantage isotope ratio mass spectrometer (Thermo Scientific). Soils' FAMEs' stable carbon isotopic composition was measured using a Trace $1310 \mathrm{GC}$ instrument interfaced online via a GC-Isolink II to a Conflo IV and Delta V Plus isotope ratio mass spectrometer (Thermo Fisher Scientific). A DB $5 \mathrm{~ms}$ column (J \& W DB-5MS, $50 \mathrm{~m} \times 0.2 \mathrm{~mm}$ i.d., $0.33 \mu \mathrm{m}$ film thickness) was used. The GC temperature pro- 
gram was $70{ }^{\circ} \mathrm{C}$ (held $4 \mathrm{~min}$ ) to $150{ }^{\circ} \mathrm{C}$ at $20^{\circ} \mathrm{C} \mathrm{min}{ }^{-1}$ and afterwards to $320^{\circ} \mathrm{C}$ (held $40 \mathrm{~min}$ ) at $5^{\circ} \mathrm{C} \mathrm{min}-1$. He was used as carrier gas at a constant $1 \mathrm{~mL} \mathrm{~min}^{-1} . \mathrm{CO}_{2}$ of known $\delta^{13} \mathrm{C}$ composition was automatically introduced via Conflo IV into the isotopic ratio mass spectrometer in a series of five pulses at the beginning and four pulses at the end of each analysis, respectively, and used as reference gas during every measurement. The comparability of soils and lake sediment results was ensured by triplicate measurements of three lake samples realized on both instruments. Each sample was measured at least three times. Carbon stable isotope ratios were reported in delta notation, per mil deviation from Vienna Pee Dee Belemnite (VPDB). The instruments' performance was routinely checked with an external isotopically characterized FA mixture (F8-3) obtained from Arndt Schimmelmann (see http://pages.iu.edu/ aschimme/hc.html, last access: 14 May 2019), to which a mixture of isotopically characterized C24:0, C26:0, C28:0 and C30:0 FAMEs was added. Performance was controlled with a C19:0 FA internal standard. The reported $\delta^{13} \mathrm{C}$ values were corrected for the additional carbon atom introduced during methylation. Mean values of at least triplicate measurements, as well as their corresponding standard deviation, were calculated. The analytical uncertainty is lower than $\pm 0.5 \%$. Only long-chain FAs $\geq$ C24:0 were investigated. These are characteristic of the higher plant input into the soil (Eglinton and Eglinton, 2008). Short- or mid-chain FAs can also be produced by bacteria or aquatic plants and would bias our approach to trace back the terrestrial input into the lake.

\subsubsection{Triterpenoids}

The neutral fraction (including the cyclic biomarkers considered in this study) was further separated into aliphatics, aromatics, ethers and esters, ketones and acetates and alcohols using flash chromatography on a Pasteur pipette filled with activated silica $\left(24 \mathrm{~h}\right.$ at $120^{\circ} \mathrm{C}$, then deactivated with $5 \% \mathrm{H}_{2} \mathrm{O}$ ) and using a sequence of solvents of increasing polarity. The alcohol fraction was silylated before injection by reaction with N,O-bis-(trimethylsilyl)trifluoroacetamide (BSTFA) containing $1 \%$ trimethylchlorosilane and pyridine for approximately $1 \mathrm{~h}$ at $60^{\circ} \mathrm{C}$. $5 \alpha$-cholestane, which was used as an internal standard, was added to all fractions, prior to analysis by gas chromatography-mass spectrometry (GC-MS) with a Trace GC Ultra coupled to a DSQII mass spectrometer (Thermo Fisher Scientific). The GC instrument was fitted with a Restek Rxi-5 ms column $(60 \mathrm{~m} \times 0.25 \mathrm{~mm}$ i.d., $0.25 \mu \mathrm{m}$ film thickness). Samples were injected in splitless mode, with the injector temperature set at $300^{\circ} \mathrm{C}$. He was the carrier gas at a constant flow of $1.2 \mathrm{~mL} \mathrm{~min}^{-1}$. The GC temperature program was $50^{\circ} \mathrm{C}$ (held $2 \mathrm{~min}$ ) to $140^{\circ} \mathrm{C}$ (held $1 \mathrm{~min}$ ) at $10^{\circ} \mathrm{C} \mathrm{min}^{-1}$, then to $300{ }^{\circ} \mathrm{C}$ (held $63 \mathrm{~min}$ ) at $4^{\circ} \mathrm{C} \mathrm{min}^{-1}$. The transfer line to the MS detector was operated at $260^{\circ} \mathrm{C}$. The mass spectrometer was operated in the electron ionization (EI) mode at $70 \mathrm{eV}$ and scanned from $m / z \quad 40$ to 1000 . Component identification was based on comparison with literature data.

\section{Results and discussion}

\subsection{CSIA of potential source soils}

Among the FAs detected in soils (C17:0 to C32:0), only the longer chains, i.e. longer than $\mathrm{C} 24: 0$, were further considered for this study to limit errors due to aquatic organisms' contribution (Alewell et al., 2016). Though present in soils, C30:0 and $\mathrm{C} 32: 0$ were not further considered here as their concentration that is too low (C30:0) or their absence (C32:0) in the lake sediments hampers their use for fingerprinting. Figure 3 displays the CSIA isoplots for the C24:0 vs. C26:0, C26:0 vs. C28:0 and C24:0 vs. C28:0. Data are provided in Table S1. The C26:0 vs. C28:0 plot shows the best discrimination between the different land-use types.

All the samples align along a line of which ends are the isotopic signals of the grasslands and the forests soils. Halfway between them, the orchard signature probably holds a mix between the inputs of the fruit trees, of which signature might be supposed to be comparable to forest trees, and of the underlying grass. The values of one orchard sample are in between the forest pool. Being covered with the same tree species as the other orchards (apple trees), and the age of the orchard having no influence on the measured imprint (Table S3), it is most probable that the corresponding sample was taken nearer to the trees than the other ones. CSIA signatures of arable lands are close to the orchards' values. The good separation between grasslands and forest pools confirms the results published on the Enziwigger catchment (ca. $30 \mathrm{~km}$ west of Lake Baldegg; Alewell et al., 2016), but our results show a better distinction between arable lands and grasslands - which could not be separated in this previous study. This can be either due to the greater surface covered with maize in the Lake Baldegg catchment (ca. $10 \%$ of agricultural land in 2015; Federal Statistical Office) compared to the Enziwigger catchment, where the low maize production does not produce any detectable effect on the stable isotope signature of soils (Schindler Wildhaber et al., 2012), or to more frequent rotation of grasslands and arable crops in the Enziwigger study. As we cannot exclude temporary grasslands being part of crop rotations including cereals, we expected temporary grassland values to be close to the arable land signal at Lake Baldegg. But CSIA signatures cannot distinguish between non-permanent and permanent grasslands. As mean residence times of one to several decades were reported for lipid fractions in croplands, permanent grasslands and forests (Wiesenberg et al., 2004, 2008; Griepentrog et al., 2015, respectively), the rapid loss of an arable land imprint after rotation to grassland seems unlikely. Most probably, the corresponding non-permanent grasslands are, even though regularly ploughed and the vegetation regularly re- 

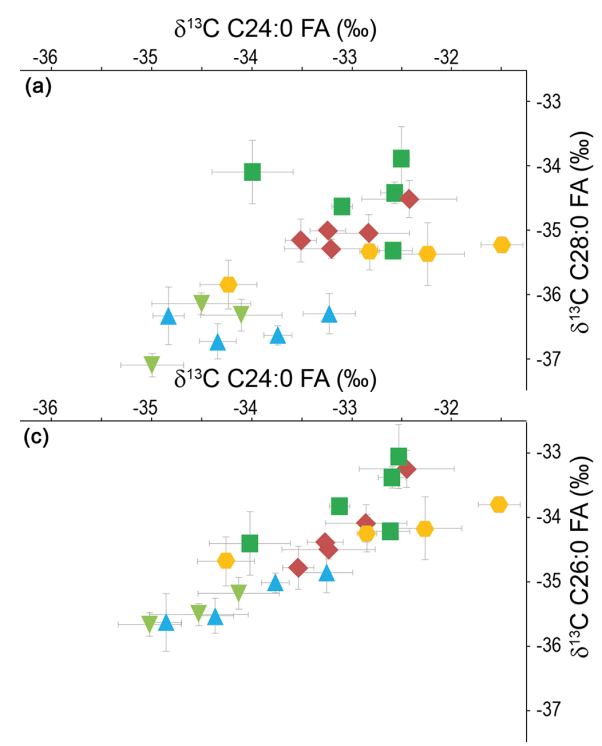

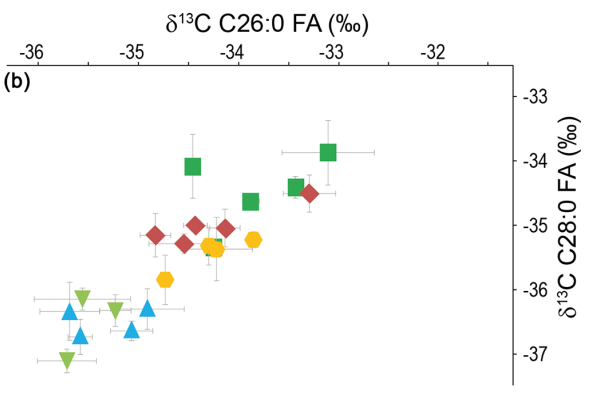

Source soils

Forests

- Orchards

$\triangle$ Temporary grasslands

$\checkmark$ Permanent grasslands

Figure 3. $\delta^{13} \mathrm{C}$ of the FAs (a) C24:0 vs. C28:0, (b) C26:0 vs. C28:0 and (c) C24:0 vs. C26:0 in soils. Error bars: standard deviation of the triplicate measurements.

sowed, used mostly as grasslands for many years, resulting in an imprint comparable to the permanent grasslands one. Further inquiries with local farmers confirmed that most temporary grasslands were just ploughed and reseeded to control for homogenous and highly productive species distribution.

\subsection{CSIA of lake sediments}

Considering the very low concentration of the C30:0 FA in the lake sediment, only the C24:0, C26:0 and C28:0 homologues were considered here to avoid any biases due to a concentration effect (Fig. 4). Data are provided in Table S2. The isotopic signature of the samples older than 1940 and from 1964 to 1972 falls out of the source soils' mixing polygon, making the use of a mixing model to quantify the contribution of different land uses to sediment inputs impossible. This mismatch between soil and most of the lake sediment signals indicates that we did not catch all contributing sources to the lake sediment FA isotopic signal.

\subsubsection{The likelihood of missing an additional terrestrial source to the isotopic FA signal of lake sediments}

Land use and land-use change is exceptionally well documented in this Swiss catchment. Vegetation composition did not dramatically change during the last century, and, to the best of our knowledge, there are no plausible additional landuse types as soil sources to the lake sediments we might have missed over the last decades. Any input from sewage sludge or from pig faeces originating from the intensive farming attested since the mid-1960s around the lake can be excluded, even before the introduction of wastewater treatment plants in the late 1960s, since both are not known to be sources of long-chain saturated FAs (Cummings, 1981; Jørgensen et al., 1993; Jardé et al., 2005; Réveillé et al., 2003, respectively).

The input of organics from humus material and mixing into the lake sediments might be discussed as a potential additional source. However, great care was paid to remove any macroscopic organic material from the sieved soil and lake sediment samples. Even if we missed some highly decomposed Oa material, a study about fractionation processes of FAs in the humus layer of forest soils in the Lake Baldegg catchment recorded no or only slight changes in the isotopic signal from the $\mathrm{Oa}$ to the Ah horizon (unpublished data). For our site with the Oa horizon, C28:0 and C30:0 FAs were only slightly depleted by 0.2 to $0.3 \%$ o compared to the $\mathrm{Ah}$ horizon. $\mathrm{C} 24: 0$ and $\mathrm{C} 26: 0$ were depleted by $0.8 \%$ and $1 \%$ o respectively. But these humus $\delta^{13} \mathrm{C}$ values are $-33.8 \%$ for C26:0 FA and $-34.6 \%$ for C28:0 FA and can thus not explain shifts of $\mathrm{C} 26: 0 / \mathrm{C} 28: 0$ to values more negative than $-36 \%$ (compare Fig. 4). Further, these humus $\delta^{13} \mathrm{C}$ values still lie in the isotopic range of the five analysed forest locations (Fig. 4) and would not be separable as a discrete source. Also, as today's isotopic signals of lake sediment samples are plotted within the polygon of the source soil signals, we rather expect a source or process different from today's conditions to be the cause for the deviation of isotopic signals.

Historical research (Kopp, 1962) has revealed that the lake level was lowered by 30 to $40 \mathrm{~cm}$ at the beginning of the 19th century. This lake level change has changed the hydrology of riparian zones and wetlands, which have drained into the lake and were drained by the farmers to use the fertile riparian area. As such, organic material from wetland soils (e.g. fens, riparian zones) might have been leached and eroded due to the change in hydrological regime and/or drainage 


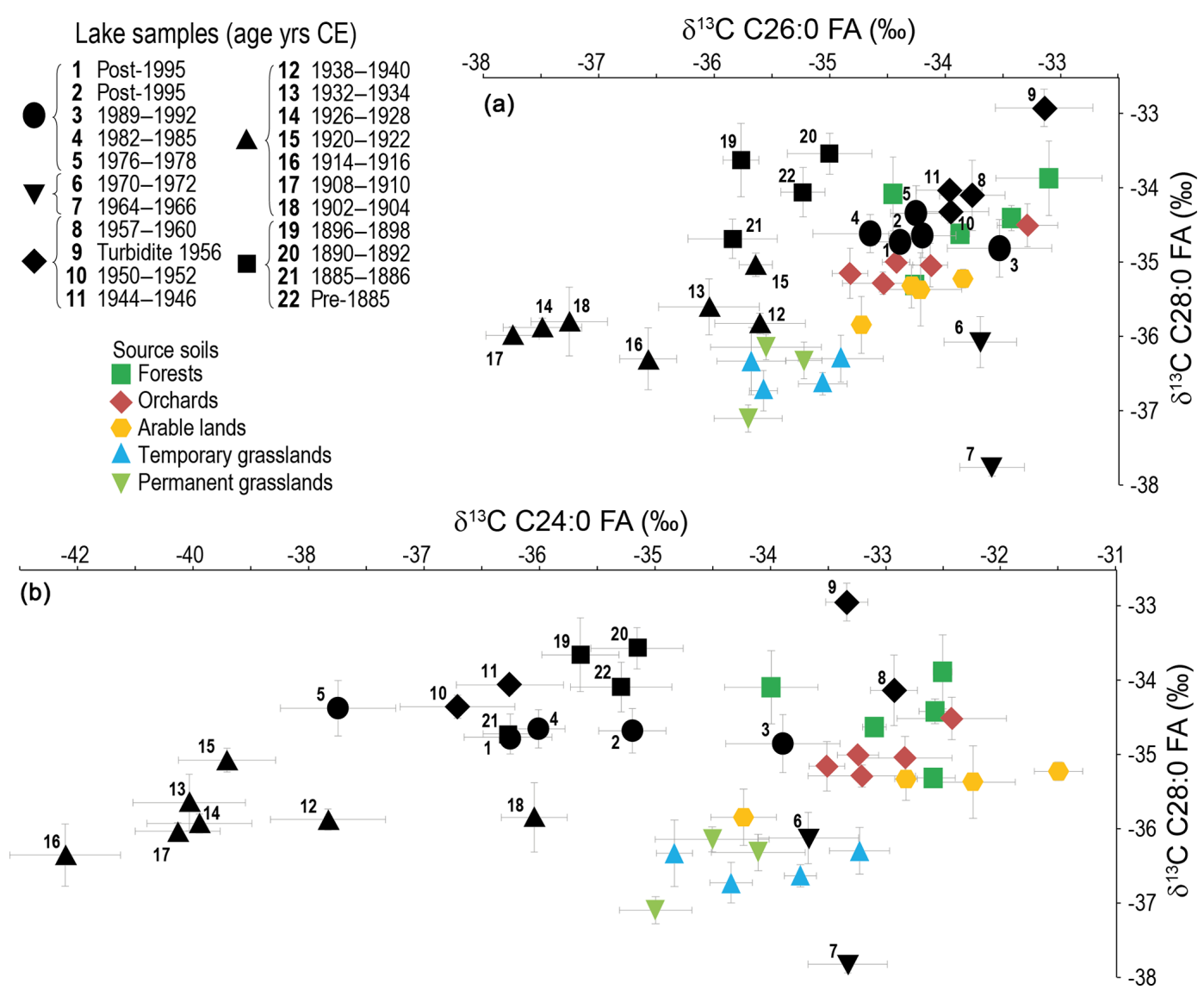

Figure 4. $\delta^{13} \mathrm{C}$ of the FAs (a) C26:0 vs. C28:0, (b) C24:0 vs. C28:0, in lake sediments, compared to soils. Note the different scale for the $x$ axis between (a) and (b). Error bars: standard deviation of the triplicate measurements.

of sites due to adapted land use. Furthermore, established reedlands, with Phragmites australis, next to the main inflow at the southern end of the catchment have been cut, starting in 1944, and in 1955 they completely drained this reedland. Today this area is a small lake with small surrounding wetlands, still containing Phragmites australis (Rezbanyai, 1981). As such, another possible explanation for the negative values of the FAs C24:0 and C26:0 could be a larger contribution of wetland organic matter, derived from, for example, Phragmites australis or Sphagnum species, to the eroded sediments. Especially Sphagnum species comprise high concentrations of C24:0 and C26:0 FAs (Baas et al., 2000; Pancost et al., 2002). Photosynthesis of Phragmites or mosses like Sphagnum in the riparian zone or in peats respectively, with $\mathrm{CO}_{2}$ derived from oxidized methane, could be an optional source for depleted long-chain FAs (see Alewell et al., 2011; $\delta^{13} \mathrm{C}$ depletion of mosses, induced by photosynthesis with methane-derived $\mathrm{CO}_{2}$, affected the bulk carbon $\delta^{13} \mathrm{C}$ in Scottish bog). However, $\delta^{13} \mathrm{C}$ values of long-chain FAs from a Scottish peat core were not depleted and range between $-29.5 \%$ and $-32.8 \%$ (Ficken et al., 1998) and would not be an adequate explanation for our missing source. Nevertheless, a depleted $\delta^{13} \mathrm{C}$ signal of $\mathrm{C} 24: 0$ and C26:0 FAs from wetlands or peat could explain the deviation for most of our lake sediment samples. Even more so, if we consider the relatively low C28:0 FA concentration in Sphagnum (Baas et al., 2000; Pancost et al., 2002) compared to C24:0 and C26:0 FAs. The larger proportions of C24:0 and C26:0 FAs would clearly dominate over the C28:0 FA signal and could explain the stronger shift of the lake sediments to more depleted C24:0 and C26:0 FA $\delta^{13} \mathrm{C}$ values compared to a C28:0 FA $\delta^{13} \mathrm{C}$ signal, dominated by the other land-use types. This hypothesis cannot be tested in retrospect, as these reedlands and wetlands disappeared 50-75 years ago, but it seems to be one possible explanation for the isotopic depletion of the FAs before 1940, especially if we consider the high concentration of C24:0 in Sphagnum (see Baas et al., 2000; Pancost et al., 2002).

\subsubsection{The likelihood of missing an in situ source to the isotopic FA signal of lake sediments}

One potential missed source might be the influence of complete organisms or residues of e.g. chironomid larvae on the $\delta^{13} \mathrm{C}$ signal of the lake sediment. FAs produced by these larvae might be depleted in $\delta^{13} \mathrm{C}$ (Makhutova et al., 2017) and 
could act as a potential depleted source. However, sample preparation was done, paying attention to the possible occurrence of chironomid larvae, and we can thus exclude the presence of these organisms in relevant amounts. Moreover, no literature was found stating the production of FAs longer than C22:0 by these larvae.

Other sources for long-chain FAs might be lacustrine macrophytes and microbial organisms (e.g. Volkman et al., 1988, 1998; Bovee and Pearson, 2014; Schouten et al., 1998; van Bree et al., 2018), but no reference to the production of long-chain FAs by organisms known to live in Lake Baldegg could be found: the algae responsible for the blooms (toxic blue algae Aphanizomenon and Anabaena during the 1960s, green algae Pediastrum especially between 1965 and 1970; Stadelmann et al., 2002; van der Knaap et al., 2000) are indeed not known to produce long-chain saturated FAs (Gugger et al., 2002; Caudales and Wells, 1992; Parker et al., 1967; Blokker et al., 1998). Very recently, van Bree et al. (2018) suggested the production of long-chain FAs, mainly C28:0, in the water column by algae or bacteria, while studying suspended particulate matter (SPM) from Lake Chala (Kenya/Tanzania). They draw their conclusions from a very strong seasonal variability in the SPM, different timing of the maximum concentrations of long-chain $n$ alkanes and long-chain FAs and very negative $\delta^{13} \mathrm{C}$ values down to $-46.3 \%$ o for $\mathrm{C} 28: 0 \mathrm{FA}$ and $-41.9 \%$ o for $\mathrm{C} 26: 0$ FA. One possible explanation for the very depleted $\delta^{13} \mathrm{C}$ values of the FAs was the dissolution of $\mathrm{CO}_{2}$ into undersaturated lake water. During times of undersaturation with $\mathrm{CO}_{2}$ and high $\mathrm{pH}$ values (8.3 to 9) the dissolution of atmospheric $\mathrm{CO}_{2}$ into the lake water is enhanced, and the $\mathrm{CO}_{2}$, instead of with $\mathrm{H}_{2} \mathrm{O}$, reacts with $\mathrm{OH}^{-}$to form $\mathrm{HCO}_{3}^{-}$(hydroxylation of $\mathrm{CO}_{2}$ ). This reaction results in a strong carbon isotopic fractionation of $-15 \%$, compared to $+8 \%$ o during the reaction with $\mathrm{H}_{2} \mathrm{O}$. This highly depleted $\mathrm{HCO}_{3}^{-}$can be taken up as a carbon source and can thus heavily influence the isotopic signal of FAs produced by aquatic organisms (van Bree et al., 2018, and references therein; Teranes et al., 1999, and reference therein, describing the same process for depleted $\delta^{18} \mathrm{O}$ in Lake Baldegg).

As we have general conditions of $\mathrm{CO}_{2}$ undersaturation in Lake Baldegg beginning at the end of April when stratification is starting and epilimnic primary production is increasing (Müller et al., 2016), the above-described incorporation of atmospheric $\mathrm{CO}_{2}$ into FAs might also serve as a possible explanation for the depleted values of C24:0 and C26:0. Also $\mathrm{pH}$ values during that time of the year are above 8.3 and reach 8.6 during June (Teranes et al., 1999), and hydroxylation of $\mathrm{CO}_{2}$ will be a dominant process.

We noted that the shorter the homologue is, the more deviated from the soils' polygon its isotopic values are: while the soil values have a range of $\pm 3.5 \%$ for $\mathrm{C} 24: 0, \pm 2.6 \%$ or $\mathrm{C} 26: 0$ and $\pm 3.2 \%$ for $\mathrm{C} 28: 0$, the lake values have a range of $\pm 9, \pm 5$ and $\pm 5 \%$, respectively. For long-chain FAs of close chain length, the $\delta^{13} \mathrm{C}$ values are generally in a range of a few permil because of their common biosynthesis pathway (Hayes, 1993; Wiesenberg et al., 2004). However, we observe considerable differences between isotopic signatures of the long-chain FAs. Both the greater variation of the CSIA values in the lake compared to the soils as well as the discrepancies of up to 7\%o between C24:0 and C28:0, as observed here in lake sediments, suggest that an aquatic process might have masked the terrestrial isotopic signatures. Maybe similar to Lake Chala (van Bree et al., 2018), in Lake Baldegg the FAs C24:0 and C26:0 are primarily produced by an algal or bacterial source, whereas C28:0 still reflects the signal of the terrestrial vegetation. However, we do not see any increase in concentration of C24:0 or C26:0 FA in the lake sediments until 1940 compared to today's soils (compare Figs. S1 and S2 in the Supplement). As a result of an enhanced in situ production of long-chain FAs masking the terrestrial FA isotopic signal, we would expect higher concentrations of the FAs concerned in the lake sediment, namely C24:0 FA and C26:0 FA, compared to the non-affected C28:0 FA. But since the FA concentration patterns (e.g. relation to each other) of the sediments are not significantly different from the soils (Fig. S2), this expectation is not fulfilled. However, we do not know the historic FA content of source soils.

The depleted $\delta^{13} \mathrm{C}$ values might also be linked to bacterially assimilated carbon, associated with anoxic conditions in the water column, sediments or wetland soils (Summons et al., 1994; Teranes and Bernasconi, 2005). Biogenic methane carbon typically shows $\delta^{13} \mathrm{C}$ values of $-50 \%$ o to $-70 \%$ o (Whiticar, 1999), leading to a very depleted methanotrophic bacterial biomass (e.g. Summons et al., 1994; Lehmann et al., 2004). The influence of the methanotrophic bacterial communities in Lake Baldegg was already underlined by the study of Teranes and Bernasconi (2005). A $\delta^{13} \mathrm{C}$ value of $-70 \%$ $\pm 15 \%$ o for methanotrophic bacteria using biogenic methane can be assumed (Lehmann et al., 2004, and references therein). In this case only little bacterial biomass would be needed to cause depletion effects like we observe in the Lake Baldegg sediments. Additionally, $\delta^{13} \mathrm{C}$-depleted $\mathrm{CO}_{2}$ produced by methane-oxidizing bacteria (MOB) would result in the depleted long-chain FAs. Algae or Cyanobacteria could take up this depleted $\mathrm{CO}_{2}$ and produce on their part depleted FAs (Naeher et al., 2014). But the presence of these long-chain FAs produced in the lake so far seem to have been unlikely here, since, to the best of our knowledge, reports about the production of long-chain FAs by bacteria or algae are rare and constrained to extreme environments (e.g. Antarctic Ace Lake, Volkman et al., 1988, 1998; van Bree et al., 2018). Gong and Hollander (1997) suspected that marine bacteria contributed depleted long-chain FAs to the formerly assumed terrestrial long-chain FA pool in marine sediments. Also Feakins et al. (2007) described the in situ production of long-chain FAs in a lacustrine environment by algae or bacteria as very likely. In their study it was not the depletion of the FAs that led to this conclusion but the ratios between $n$-alkanes and FAs. 
In a recent publication, Petrišič et al. (2017) reported $\delta^{13} \mathrm{C}$ values of $-40.0 \%$ to $-43.3 \%$ for $\mathrm{C} 26: 0 \mathrm{FA}$ from surface sediments from Lake Bled, Slovenia. They suspected either methanotrophic bacteria or Cyanobacteria to be the producers of C26:0 FA. Pertrišič's findings from Lake Bled give strong evidence that bacteria can also play an important role in the in situ production of long-chain FAs in lakes beyond extreme environments. This leaves the unanswered question as to why C24:0 FA in the Lake Bled sediments is not depleted, or only slightly depleted, with $\delta^{13} \mathrm{C}$ values ranging from $-36.3 \%$ o to $-37.7 \%$. Unfortunately, no data for C28:0 FA from Lake Bled are available (Petrišič et al., 2017). As explained above, the influence of the unknown source in Lake Baldegg sediments increases from C26:0 to C24:0 FA. However, Neunlist et al. (2002) presented isotopic data for C24:0C28:0 FA from Lake Bled and Lake Baldegg sediment samples. Interestingly, in the two more recent sediment samples from Lake Bled, 1993 to 1996 and 1984 to 1990, no depletion of the $\delta^{13} \mathrm{C}$ values was observed, whereas the two older samples from 1967 to 1976 and 1943 to 1956 show a clear isotopic depletion. The authors suggested a continuous change in the isotopic composition of the carbon source of the producing organisms. For Lake Baldegg, four sediment samples from different depths were analysed, but in contrast to our study, no significant depletion of the FA $\delta^{13} \mathrm{C}$ values was observed. However, none of the investigated samples originated from a time when we observed the strong isotopic depletion of C26:0 and C24:0 FA in Lake Baldegg. Neunlist et al. (2002) concluded that there were constant stable sources for the linear compounds and that a higher plant origin was very likely.

Taking all this into account, the likelihood of the in situ production of long-chain FAs by aquatic organisms like algae or bacteria is given. The most likely was algal (phytoplankton) production caused by uptake of depleted $\mathrm{HCO}_{3}^{-}$ due to the undersaturation of $\mathrm{CO}_{2}$ in the surface water, high $\mathrm{pH}$ values and associated hydroxylation of $\mathrm{CO}_{2}$ (van Bree et al., 2018) or production by methanotroph bacteria and/or by algae or Cyanobacteria which used $\mathrm{CO}_{2}$ depleted in $\delta^{13} \mathrm{C}$, formerly produced by MOB (Naeher et al., 2014; Petrišič et al., 2017).

\subsubsection{The necessity of Suess effect correction for terrestrial lipids in lake sediments}

The $\delta^{13} \mathrm{C}$ value of atmospheric $\mathrm{CO}_{2}$ has decreased by approximately $2 \%$ since the beginning of the industrial era in response to fossil fuel combustion (atmospheric $\delta^{13} \mathrm{C}=-6.5 \%$ in the pre-industrial era vs. $-8.5 \%$ o today; Rubino et al., 2013; Keeling et al., 2005; Verburg, 2007, respectively). Therefore, we would expect older lake sediment samples to be relatively enriched (less depleted) in $\delta^{13} \mathrm{C}$ compared to our present-day source soils or sediments. As such, the Suess effect cannot explain our deviation of the isotopic signals between source soils polygon and lake sed- iments. However, it is widely recognized as being necessary to correct for the Suess effect in autochthonous organic matter (Verburg, 2007). We thus want to discuss in the following the application of this correction for terrestrial-derived organic matter in lake sediments (in our study long-chain FAs are biomarkers for higher plants; Eglinton and Eglinton, 2008).

Long-term experiments have shown that because a depletion due to the Suess effect is well recorded in plants (e.g. Zhao et al., 2001), this effect should also be recorded in soils and consequently also in organic terrestrial markers archived in lake sediments, such as FAs. However, the Suess effect can only account for a maximum decrease of ca. $2 \%$ in the atmosphere or, taking the dataset of Zhao et al. (2001) for straw from 1845 until 1997 into account, an enhanced depletion of $2.5 \%$ in the biomass compared to $1.5 \%$ depletion in the atmosphere at the end of the 1990s. And it might only have an influence in the case of a soil comprising a short mean residence time of the overall soil organic matter of one to a few years (Garten et al., 2000). Longer mean residence times necessarily imply a time lag in the recording of the Suess effect in soils, accompanied with a strong dampening of the incoming isotopic signal.

To estimate the Suess effect on our soils and sediments, we did a correction based on the atmospheric $\mathrm{CO}_{2}$ curve of Verburg (2007). We applied Eq. (1) to calculate the Suesseffect-induced changes from year to year, with 1840 as the starting point.

$$
\begin{aligned}
\delta^{13} \mathrm{C}_{\text {Soil }(t+1)}= & (1-1 / R){ }^{13} \mathrm{C}_{\text {Soil }(t)}+1 / R\left(\delta^{13} \mathrm{C}_{\text {Soil }(t 0)}\right. \\
& \left.+\left(\delta^{13} \mathrm{C}_{\mathrm{Atm}(t+1)}-\delta^{13} \mathrm{C}_{\mathrm{Atm}(t 0)}\right)\right),
\end{aligned}
$$

where $t$ is the year of observation with $t=0$ equal to 1840 , and $R$ is the mean residence time for the FAs in years. Further we assumed no changes in $\delta^{13} \mathrm{C}$ of atmospheric $\mathrm{CO}_{2}$ before 1840 and calculated the changes afterwards following the values of atmospheric $\mathrm{CO}_{2}$ of Verburg (2007). The soil organic carbon pool size was assumed to be stable over the time, and no changes in isotope fractionation during photosynthesis due to a concentration increase in $\mathrm{CO}_{2}$ were considered.

We assumed three different mean residence times for organic material in the soil of 10, 30 and 100 years, which are discussed in soil science (Lichtfouse, 1997; Six and Jastrow, 2002; Wiesenberg et al., 2004). For a better comparability, both soils and sediments were Suess-effect-corrected, following Eq. (1), to pre-industrial values (1840), as was also done when correcting tree rings for the Suess effect (McCarroll et al., 2009) (for results, please see Figs. S4-S7 and Tables S4-S5). For the shortest mean residence time the resulting maximum effect is a depletion of $-1.82 \%$ from 1840 until 2015 for the soils. For the lake sediments the maximum depletion is $-1.63 \%$ o between 1840 and 2010 . The older the sediments, the smaller the Suess effect. For a mean residence time of 100 years, we observe smaller changes for the soils 
and sediments, of $-0.65 \%$ and $-0.58 \%$, respectively. Despite all uncertainties and simplifications, we can expect that the Suess effect will also affect the FAs deposited in the lake sediments. Thus, it is important to apply this correction also to the sediments, since the terrestrial-derived long-chain FAs in the sediment express the $\delta^{13} \mathrm{C}$ status of the soil in the year of deposition and therefore have to be corrected in parallel to the soils.

Our results in calculating the Suess effect are considerably higher than previously discussed in the literature from measurements of archived soil samples. A shift of $0.2 \%$ to $0.3 \%$ in $\delta^{13} \mathrm{C}$ (i.e. in the range of the measurement precision) was measured in arable temperate soil samples from the 1960s compared to 2000s, i.e. during the period when the Suess effect would be most relevant (Wiesenberg, 2004). Congruently, a $0.1 \%$ to $0.3 \%$ shift related to the Suess effect was measured for a tropical soil with an estimated mean residence time for soil organic carbon of $<10$ years by Bird et al. (2003). The considerably lower measured effects of the Suess effect compared to our calculated effects might be due to either (i) the ploughing of arable soils or non-permanent grasslands, which results in a mix of young and old organic matter, or (ii) considerably longer mean residence times in soils than we assumed for our calculations.

However, with the new findings in our study and others (Petrišič et al., 2017; van Bree et al., 2018), the production of long-chain FAs within the lake has to be considered (see above for discussion). In this case, the Suess effect has a direct link to the autochthonous-produced FAs, and a correction for the resulting growing depletion with time should be carried out if the ratio between autochthonous-produced and soil-derived organic matter is known. Since the responsible algae, bacteria or microorganisms are not yet identified, and the $\delta^{13} \mathrm{C}$ source signal is not yet known, a serious correction for the Suess effect is not possible. Therefore a correction for the Suess effect in this study would be very speculative (please note that we document the Suess-effect-corrected values in Figs. S4-S7 and Tables S4-S5).

\subsubsection{Eutrophication, lake and catchment history, in the light of the CSIA}

As the data indicate that the C24:0 signal is the most affected of the three homologues considered, the following discussion will focus on the C26:0 vs. C28:0 signals (Fig. 4), which were also the homologues allowing the best distinction between land uses in the source soils (Sect. 4.1.).

The C26:0 vs. C28:0 CSIA allows a distinction of different units (Fig. 4): before 1900, 1900 to 1940s, 1940s to early 1960 s, early 1960 s to early 1970 s and early 1970 s to today. These units confirm the land-use changes along different time periods discussed in previous studies conducted on the lake (e.g. based on diatoms' succession, bulk carbon isotopes, eutrophication history; Lotter, 1998; Teranes and Bernasconi, 2005; Stadelmann et al., 2002, respectively), which attests to the reliability of the CSIA signal to discuss the lake and catchment history.

The oldest sediment samples are deposited prior to the eutrophication start, which began in 1885 , from (1) phosphorus concentrations inferred from the diatom assemblages and (2) the appearance of varves in the sediment sequence (Lotter et al., 1997; Lotter, 1998). At the onset of the 20th century, a deviation in the C26:0 CSIA data towards lower values is recorded (Fig. 4a), while simultaneously a first important step in eutrophication is reached. Indeed, at that time, the microbial biomass increases (Teranes and Bernasconi, 2005), and a change in diatoms assemblage is recorded (Lotter, 1998), in response to the important industrial development of the catchment and the associated massive wastewater inputs into the lake.

In the early 1940s, a strong shift towards higher values is recorded in the C26:0 CSIA data signal (Fig. 4a). The lake then enters a severe eutrophication period, marked by an increased influence of the bacterial communities (Neunlist et al., 2002; Teranes and Bernasconi, 2005). Lake water is anoxic below $40 \mathrm{~m}$ depth (Niessen and Sturm, 1987). The influence of the land-use changes on the lake response deserves consideration. Indeed, as a result of the Wahlen Plan, a Swiss food self-sufficiency program launched at the beginning of the Second World War, and arable lands expanded at the country scale (Popp, 2001). In the Lake Baldegg catchment, surfaces dedicated to open lands are multiplied by a factor of 3.6 between 1934 and 1945; they even increase by a factor of 4.1 for cereals (Federal Statistical Office, 1949). Maize is introduced in the catchment during the 1940s, but its dedicated surface is under 3 ha in the mid-1940s and remains small until the 1980s (Federal Statistical Office, 1949; Lotter, 2010). No other cereal is introduced, but the relative proportion of winter wheat strongly increases (Federal Statistical Office, 1949). The agricultural intensification is reflected in the decline of grassland species, the decrease of ruderals of poor soils, the increase of Urtica and the appearance of Ambrosia, the latter testifying to soil destructuration (pollen analyses of van der Knaap, 2000; Ducerf, 2017). According to air photographs, forest composition also changes to include more coniferous trees, and forest roads develop. In addition, agricultural intensification leads to intense river corrections: for instance, in the western part of the catchment, four small rivers were buried in the 1940s. Such corrections, accompanied by the development of a drainage system, continue until the 1960s.

The isotopic excursion begins in the early 1960s (Fig. 4a), as the lake tends towards its most severe hypertrophic conditions, with a hypolimnion anoxia from $10 \mathrm{~m}$ depth (Niessen and Sturm, 1987). The strongly increasing phosphorus concentration fosters the development of photoautotrophic biomass, while the chemautotrophic bacterial biomass is still largely present in the lake though declining (Teranes and Bernasconi, 2005). This anoxic phase is synchronous with 
increased sewage sludge inputs as well as with a strong intensification of pig breeding in the catchment.

This isotopic excursion ends with the introduction of wastewater treatment plants in the catchment (Stadelmann et al., 2002). Later, the artificial oxygenation system set-up in the lake in 1982 allows the return to oxic conditions at the bottom of the lake. This favours the development of phytoplanktonic producers, at the expense of the chemautotrophic biomass (Teranes and Bernasconi, 2005).

It is worth noting that from the mid-1940s, all the lake samples (except the isotopic excursion of the early 1960s to early 1970s) fall into the source soil polygon (Fig. 4a), suggesting that these samples are not affected, or very little affected, by depleted organic material from the unknown source. All the CSIA data of these samples from the forest, arable land and orchard areas fall into the polygon of the source soils' signatures. While the sediment contribution from the arable lands can be explained by its associated discontinuous land cover and the agricultural practices (ploughing), the contribution of the forest pool is more surprising. However, most of the forests develop on steep slopes in the catchment, favouring the export of forest soil material towards the lake. In addition, sedimentary inputs into Lake Baldegg occur mainly during high flow events, of which CSIA imprints were also shown to be dominated by forest contribution in a nearby catchment (Enziwigger catchment; Alewell et al., 2016). Furthermore, the development of trees and shrubs along the streams and on the shores of the lake since the 1940s (air photographs, pollen analysis; van der Knaap, 2000; field observation) may contribute directly to the signal.

\subsubsection{General considerations}

While the units defined using CSIA match well with the eutrophication and the catchment history, it is remarkable that the oldest sediments (older than 1940) seem to be more affected by depleted material than the younger ones (except the isotopic excursion of the mid-1960s to mid-1970s). Indeed, the maximal extent of the chemautotrophic biomass activity takes place during the most severe eutrophication periods of the lake, i.e. after 1940. But this could also be explained by a change in the presence or abundance of the in situ producers of long-chain FAs accompanying the change of the lake's trophic status. It is also worth noting that while C24:0 and C26:0 are more depleted than C28:0 for the oldest lake sediments, the opposite is observed for the excursion of the mid-1960s to mid-1970s. Changes in the microbial biomass composition, resulting in contrasted effects on the FAs' isotopic signature, are suspected. Here the example of van Bree et al. (2018) can be consulted, as they found a compoundspecific concentration increase of mostly C28:0 FA in the water column. Also, the accompanying isotopic depletion of, in their case, C28:0 FA compared to the terrestrial C28:0 FA signal gives strong evidence for an aquatic source. However, we conclude that the modelling of the different source contributions for the lake sediments cannot be conducted in this study. Any approach to deduce the isotopic signal from the data, without identifying the actual sources and their isotopic signature, would be very speculative (see Fig. S3) and would not lead to serious and concise results. Therefore, future research should focus on the identification of the aquatic producers of long-chain FAs in lacustrine environments and its isotopic composition.

\subsection{Triterpenoid biomarkers}

The occurrence of cyclic highly specific biomarkers was checked both in soils and lake sediments. Pentacyclic triterpenes such as some triterpenyl acetates, tricyclic diterpenes and methoxyserratenes (biomarkers of Asteraceae, conifers and Pinaceae, respectively; Lavrieux et al., 2011; Otto and Wilde, 2001; Le Milbeau et al., 2013) were investigated. While some non-specific molecules of these families have been identified in soils under the expected land uses, and some triterpenoids were detected in the lake sediment, the most specific of them were totally absent from the latter. The concentration of these HSB in sediments is usually lower than the more common linear compounds such as FAs (e.g. Lavrieux, 2011). Accordingly, their non-detection in the Lake Baldegg archive could be due to small undetectable inputs from the catchment or a signal dilution into autochthonous (lake organisms') contribution. In addition, a possible degradation of these pentacyclic triterpenes after their deposition can be hypothesized, although the successful use of these molecules for palaeo-environmental studies suggests their high preservation potential (e.g. Lavrieux, 2011; Guillemot et al., 2017, for triterpenyl acetates; Simoneit, 1986; Stefanova et al., 2002, for tricyclic diterpenes).

However, in all lake sediment samples, two trimethytetrahydrochrysenes (TTHCs) were detected: 3, 4, 7-trimethyl1, 2, 3, 4-tetrahydrochrysene (TTHC2) and 3, 3, 7-trimethyl1,2,3,4-tetrahydrochrysene (TTHC3). These polycyclic aromatic hydrocarbons (PAHs) of natural origin derive from the rapid diagenesis of ubiquitous pentacyclic triterpenoids of the oleanane and ursane series synthesized by upper plants (e.g. Wakeham et al., 1980). These TTHCs were reported during the last decades in recent lake sediments (e.g. Wakeham et al., 1980; Yunker and MacDonald, 1995; Jacob et al., 2008), as well as in deltaic environments (Bouloubassi and Saliot, 1993). Their formation in anaerobic conditions via microbial activity (Wakeham et al., 1980) was confirmed by the laboratory experiment of anaerobic transformation of triterpenes into PAHs by Lohmann et al. (1990). Despite their production conditions being known, it is still under debate as to where this transformation takes place and if it would depend on the study site context: the TTHCs would be synthesized either in leaf litter or in deep soils (Wakeham et al., 1980; Jacob et al., 2008) or during transport (Bouloubassi and Saliot, 1993) or produced in situ in the lake sediment 


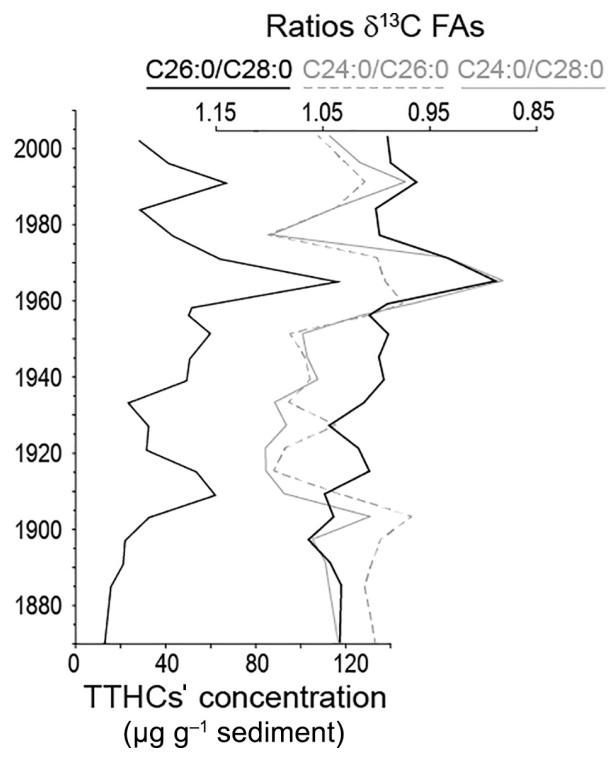

Figure 5. Evolution of the TTHCs concentration (sum of TTHC2 and TTHC3) along the sediment core, compared to evolution of the ratios of $\delta^{13} \mathrm{C}$ of FAs.

column (e.g. Bouloubassi et al., 2001; Yunker and MacDonald, 2003).

While our investigations revealed the occurrence of these TTHCs in lake core sediments, they were neither detected in the upper soils, nor in river-suspended sediments from the Lake Baldegg catchment (unpublished results). Hence, the formation of TTHCs in soils and during transport appears to be very unlikely here, although their presence in deep soils (as reported by Wakeham et al., 1980) and their subsequent transport through deep soil erosion cannot be fully excluded.

The temporal evolution of TTHCs concentration is provided in Fig. 5. The lowest concentrations are recorded in the earliest part of the archive, before the onset of the eutrophication, and they increase as the latter starts. The maximal concentration is reached in the middle of the 1960s, i.e. synchronously with the isotopic excursion recorded in CSIA. The evolution of TTHCs' concentration was compared to ratios of $\delta^{13} \mathrm{C}$ FAs $\left(\delta^{13} \mathrm{C} \mathrm{C} 24: 0 / \delta^{13} \mathrm{C} \mathrm{C} 26: 0 ; \delta^{13} \mathrm{C}\right.$ $\mathrm{C} 26: 0 / \delta^{13} \mathrm{C}$ C28:0; $\delta^{13} \mathrm{C} \mathrm{C} 24: 0 / \delta^{13} \mathrm{C}$ C28:0). There is a high discrepancy in isotopic values between long-chain FAs of close chain-length points and different major origins of the single FAs, namely an isotopically depleted aquatic contribution in addition to the expected terrestrial origin. The more the values differ (i.e. the more the ratio of their isotopic values is $>1$ or $<1$ ), the more the isotopic signal of one of the FAs can be considered to be influenced by different sources. Keeping in mind that such a ratio is not an absolute indicator because of some variability results from the biosynthesis pathway, one can still consider the overall evolution of the ratio along the core. $\mathrm{C} 28: 0$ being considered only little affected by autochthonous production, $\delta^{13} \mathrm{C} \mathrm{C} 26: 0 / \delta^{13} \mathrm{C} \mathrm{C} 28: 0$ and $\delta^{13} \mathrm{C} \mathrm{C} 24: 0 / \delta^{13} \mathrm{C} \mathrm{C} 28: 0$ ratios are taken to be more reliable than the $\delta^{13} \mathrm{C} \mathrm{C} 24: 0 / \delta^{13} \mathrm{C} \mathrm{C} 26: 0$ ratio.

Interestingly, the TTHCs' concentration evolution is highly similar to the $\delta^{13} \mathrm{FA}$ ratios' trend, even more for the $\delta^{13} \mathrm{C}$ C24:0 $/ \delta^{13} \mathrm{C}$ C28:0 than for the $\delta^{13} \mathrm{C}$ C26:0 $/ \delta^{13} \mathrm{C}$ $\mathrm{C} 28$ :0. This suggests a TTHCs' concentration under the control of the lake bacterial activity similarly to the CSIA signal. In other words, the TTHCs' signal archived in the Lake Baldegg sediments most probably testifies to an in situ degradation of pentacyclic triterpenes, consequent on the bacterial activity favoured by the anoxic conditions in the water column (Wakeham and Canuel, 2016). While these compounds have successfully been used in many contexts for palaeoenvironmental reconstructions (e.g. Lavrieux, 2011; Dubois and Jacob, 2016; Guillemot et al., 2017), our results show the impossibility of using them to decipher the terrestrial inputs in the case of the highly eutrophic and microorganismdominated Lake Baldegg environment.

Thus, the microbial activity masks to a large extent the terrestrial molecular inputs in Lake Baldegg and affects the linear compounds (as shown by the CSIA) as well as the cyclic ones (as shown by the HSB).

\section{Conclusions}

The aim of this study was to apply a mixed CSIA and HSB approach to the highly eutrophic context of the Lake Baldegg catchment. The main land uses were successfully discriminated with the CSIA but align along a line. The CSIA signals of arable lands as well as orchards are halfway between grasslands and forests, which may render the correct attribution of the sources of sediment samples lying between grasslands and forests end-members difficult. Most of the recent lake sediments are within the forest soil pool, underlining the potential important contribution either of the steeply sloping and loosely structured forest soils or to tree lines growing along the streams and around the lake, which could contribute directly to the signal transported to the lake sediment archive. Further studies are required to investigate the extent of this potential contribution. However, all lake sediments older than the 1940s, as well as those from the mid-1960s to the mid-1970s, actually fall out of the polygon of today's source soils' signatures.

Although the influence of not yet identified sources on our lake sediments, as expanded above, is very likely, the fact that the C28:0 lake isotopic values fall in the same range as the soils tends to (1) indicate that the soils are most probably the main sources of C28:0 FA but (2) indicate an additional source with depleted $\delta^{13} \mathrm{C}$ values for $\mathrm{C} 24: 0$ and $\mathrm{C} 26: 0$ FAs and, compared to the source soils, a lower concentration of C28:0 FA. This leaves a number of potential additional sources, namely, a larger contribution of Sphagnum-/mossderived organic matter released from historical peat bogs or the riparian zone as described above or, during time periods 
of hypereutrophic status of the lake, in situ FA production of preferably C24 / 26:0 FA. The latter might be produced by (i) methanotroph bacteria or other bacteria which were using $\delta^{13} \mathrm{C}$-depleted $\mathrm{CO}_{2}$ derived from methane-oxizing bacteria (MOB), (ii) in situ production by algae, which were using depleted $\delta^{13} \mathrm{C}$ from $\mathrm{HCO}_{3}^{-}$due to the described effects of the hydroxylation reaction of $\mathrm{CO}_{2}$ during times of high $\mathrm{pH}$ values in the epilimnion and $\mathrm{CO}_{2}$ undersaturation, or (iii) the algal uptake of MOB-derived $\mathrm{CO}_{2}$ depleted in $\delta^{13} \mathrm{C}$ analogous to the bacteria mentioned before.

While the long-chain FAs are becoming widely used for CSIA as markers of the terrestrial sediment contribution to rivers and lakes, our results underline the need to temper this standpoint for lake sediments. Some lacustrine macrophytes, bacteria and microbial organisms were previously also shown to produce long-chain FAs, and also our study highlights that an interference of the terrestrial isotopic signal linked to aquatic activity might be underestimated. In the case of Lake Baldegg, it was shown that, as long as the isotopic signal of the missing source is not known, it is impossible to quantitatively unmix terrestrial sources from the Lake Baldegg historic sediments and thus to apportion the relative contribution of different land uses to the sedimentary archive.

While the isotopic signal, especially C24:0 and C26:0 FAs until 1940 and C28:0 FA during the 1960s and 1970s, is clearly influenced by unknown but most likely aquatic sources, land use and catchment historical development are still surprisingly accurately reflected in the background patterns: human activities and land uses directly impacted the trophic level of the lake and its accompanying biomass, imprinting its mark on the FAs' isotopic signal. The main phases of land uses and catchment history over the last 150 years are thus still visible in the CSIA results. More than affecting just linear compounds, it is highly probable that microbial activity also affected the more specific cyclic molecule assemblages, as testified by the presence of in situ produced TTHCs. Special care should thus be taken in further studies on eutrophic systems in which a strong bacterial activity is known or suspected.

To conclude, we see the imprints of plants and bacteria in the Lake Baldegg sediments: the influence of terrestrialderived compounds and their changes with land use management are very precisely documented, but at the same time the influence of in situ-produced FAs is very likely and has an impact on the overall isotopic composition of long-chain FAs.

Data availability. All isotope data is available in the supplement. All other data are available on request from the corresponding author.

Supplement. The supplement related to this article is available online at: https://doi.org/10.5194/bg-16-2131-2019-supplement.
Author contributions. ML and $\mathrm{AB}$ contributed equally to this paper. ML performed the sampling, lab work, data evaluation, analysis and interpretation and contributed to the writing; $\mathrm{AB}$ took measurements and provided analytical support, data evaluation and interpretation and contributed to the writing; CA provided the project idea and acquisition, sampling, data interpretation and contributed to the writing; KM, GLBW and CS provided discussion and interpretation.

Competing interests. The authors declare that they have no conflict of interest.

Acknowledgements. This study was finalized in the framework of the IAEA Coordinated Research Project (CRP) "Nuclear techniques for a better understanding of the impact of climate change on soil erosion in upland agro-ecosystems" (D1.50.17). Core recovery was financially supported by an ETH research grant (CH1-02-08-2). We wish to thank Stefano Bernasconi (ETH Zurich) for granting access to the ASE and Judith Kobler-Waldis, Thomas Kuhn, Simon Imhof, Oliver Rehmann and Lukas Burgdorfer for their help in the laboratory. We thank Robert Lovas, Pius Stadelmann and Franz Stadelmann (Canton Lucerne) for providing helpful information about the catchment. Further we thank Stefano Crema and Marco Cavalli for their support in calculating the connectivity index. Our acknowledgements are also addressed to the land owners for sampling permission and their curiosity about our work.

Financial support. This research was supported by the European Cooperation in Science and Technology (grant no. ES1306).

Review statement. This paper was edited by Koji Suzuki and reviewed by two anonymous referees.

\section{References}

Alewell, C., Giesler, R., Klaminder, J., Leifeld, J., and Rol$\log$, M.: Stable carbon isotopes as indicators for environmental change in palsa peats, Biogeosciences, 8, 1769-1778, https://doi.org/10.5194/bg-8-1769-2011, 2011.

Alewell, C., Birkholz, A., Meusburger, K., Schindler Wildhaber, Y., and Mabit, L.: Quantitative sediment source attribution with compound-specific isotope analysis in a $\mathrm{C}_{3}$ plant-dominated catchment (central Switzerland), Biogeosciences, 13, 15871596, https://doi.org/10.5194/bg-13-1587-2016, 2016.

Allan, J. D.: Landscapes and riverscapes: the influence of landuse on stream ecosystems, Annu. Rev. Ecol. Evol. S., 35, 257-284, 2004.

Baas, M., Pancost, R., van Geel, B., Sinninghe-Damste, J. S.: A comparative study of lipids in Sphagnum species, Org. Geochem., 31, 535-541, 2000.

Bird, M., Kracht, O., Derrien, D., and Zhou, Y.: The effect of soil texture and roots on the stable carbon isotope composition of soil organic carbon, Aust. J. Soil Res., 41, 77-94, 2003. 
Blake, W. H., Ficken, K. J., Taylor, P., Russell, M. A., and Walling, D. E.: Tracing crop-specific sediment sources in agricultural catchments, Geomorphology, 139, 322-329, 2012.

Blokker, P., Schouten, S., van den Ende, H., de Leeuw, J., Hatcher, P. G., and Damsté, J. S. S.: Chemical structure of algaenans from the fresh water algae Tetraedron minimum, Scenedesmus communis and Pediastrum boryanum, Org. Geochem., 29, 1453-1468, 1998.

Borja, Á., Galparsoro, I., Solaun, O., Muxika, I., Tello, E. M., Uriarte, A., and Valencia, V.: The European Water Framework Directive and the DPSIR, a methodological approach to assess the risk of failing to achieve good ecological status, Estuar. Coast. Shelf S., 66, 84-96, 2006.

Borselli, L., Cassi, P., and Torri, D.: Prolegomena to sediment and flow connectivity in the landscape: A GIS and field numerical assessment, CATENA, 75, 268-277, 2008.

Bouloubassi, I. and Saliot, A.: Dissolved, particulate and sedimentary naturally derived polycyclic aromatic hydrocarbons in a coastal environment: geochemical significance, Mar. Chem. 42, 127-143, 1993.

Bouloubassi, I., Fillaux, J., and Saliot, A.: Hydrocarbons in surface sediments from the Changjiang (Yangtze River) estuary, East China Sea, Mar. Pollut. Bull., 42, 1335-1346, 2001.

Bovee, R. J. and Pearson, A.: Strong influence of the littoral zone on sedimentary lipid biomarkers in a meromictic lake, Geobiology, 12, 529-541, 2014.

Caudales, R. and Wells, J. M.: Differentiation of free-living Anabaena and Nostoc cyanobacteria on the basis of fatty acid composition, Int. J. Syst. Bacteriol., 42, 246-251, 1992.

Cavalli, M., Trevisani, S., Comiti, F., and Marchi, L.: Geomorphometric assessment of spatial sediment connectivity in small Alpine catchments, Geomorphology, 188, 31-41, 2013.

Cummings, J. H.: Short chain fatty acids in the human colon, Gut, 22, 763-779, 1981.

Dubois, N. and Jacob, J.: Molecular biomarkers of anthropic impacts in natural archives: A review, Front. Ecol. Evol., 4, 92, https://doi.org/10.3389/fevo.2016.00092, 2016.

Ducerf, G.: L'encyclopédie des plantes bio-indicatrices alimentaires et médicinales. Guide de diagnostic des sols, 4th edn., Promonature editions, France, 352 pp., 2017.

Eglinton, T. I. and Eglinton G.: Molecular proxies for palaeoclimatology, Earth Planet. Sci. Lett., 275, 1-6, 2008.

Fang, J., Wu, F., Xiong, Y., Li, F., Du, X., An, D., and Wang, L.: Source characterization of sedimentary organic matter using molecular and stable carbon isotopic composition of $n$-alkanes and fatty acids in sediment core from Lake Dianchi, China, Sci. Total Environ., 473, 410-421, 2014.

Feakins, S. J., Eglinton, T. I., deMenocal, P. B.: A comparison of biomarker recordsof northeast African vegetation from lacustrine and marine sediments (ca. 3.40 Ma), Org. Geochem. 38, 16071624, 2007.

Federal Statistical Office: Surface Agricole Utile 1975-2015, Neuchâtel (Switzerland), 2015.

Federal Statistical Office: Der Schweizerische Ackerbau in der Kriegszeit, Eidgenössische Anbauerhebungen 1939-1947, Bern, Switzerland, 360 pp., 1949.

Ficken, K. J., Barber, K. E., and Eglinton, G.: Lipid biomarker, $\delta^{13} \mathrm{C}$ and plant macrofossil stratigraphy of a Scottish montane peat bog over the last two millennia, Org. Geochem., 28, 217-237, 1998.
Galy, V., Eglinton, T., France-Lanord, C., and Sylya, S.: The provenance of vegetation and environmental signatures encoded in vascular plant biomarkers carried by the Ganges-Brahmaputra rivers, Earth Planet. Sci. Lett., 304, 1-12, 2011.

Garten, C. T., Cooper, L. W., Post, W. M., and Hanson, P. J.: Climate controls on forest soil C isotope ratios in the Southern Appalachian Mountains, Ecology, 81, 1108-1119, 2000.

Gibbs, M. M.: Identifying source soils in contemporary estuarine sediments: A new compound-specific isotope method, Estuar. Coast., 31, 344-359, 2008.

Gong, C. R. and Hollander, D. J.: Differential contribution of bacteria to sedimentary organic matter in oxic and anoxic environments, Santa Monica Basin, California, Org. Geochem., 26, 545563, 1997.

Griepentrog, M., Eglinton, T. I., Hagedorn, F., Schmidt, M. W. I., and Wiesenberg, G. L. B.: Interactive effects of elevated $\mathrm{CO}_{2}$ and nitrogen deposition on fatty acid molecular and isotope composition of above- and belowground tree biomass and forest soil fractions, Glob. Change Biol., 21, 473-486, 2015.

Gugger, M., Lyra, C., Suominen, I., Tsitko, I., Humbert, J. F., Salkinoja-Salonen, M. S., and Sivonen, K.: Cellular fatty acids as chemotaxonomic markers of the genera Anabaena, Aphanizomenon, Microcystis, Nostoc and Planktothrix (cyanobacteria), Int. J. Syst. Evol. Micr., 52, 1007-1015, 2002.

Guillemot, T., Bichet, V., Gauthier, E., Zocatelli, R., Massa, C., and Richard, H.: Environmental responses of past and recent agropastoral activities on south Greenlandic ecosystems through molecular biomarkers, Holocene, 27, 783-795, 2017.

Hancock, G. J. and Revill, A. T.: Erosion source discrimination in a rural Australian catchment using compound-specific isotope analysis (CSIA), Hydrol. Proc., 27, 923-932, 2013.

Hayes, J. M.: Factors controlling ${ }^{13} \mathrm{C}$ contents of sedimentary organic compounds: Principles and evidence, Mar. Geol., 113, 111-125, 1993.

Jacob, J., Disnar, J. R., Boussafir, M., Sifeddine, A., Albuquerque, A. L. S., and Turcq, B.: Pentacyclic triterpene methyl ethers in recent lacustrine sediments (Lagoa do Caçó, Brazil), Org. Geochem., 36, 449-461, 2005.

Jacob, J., Disnar, J. R., Arnaud, F., Chapron, E., Debret, M., LallierVergès, E., Desmet, M., and Revel-Rolland, M.: Millet cultivation history in the French Alps as evidenced by a sedimentary molecule, J. Archaeol. Sci., 35, 814-820, 2008.

Jardé, E., Mansuy, L., and Faure, P.: Organic markers in the lipidic fraction of sewage sludge, Water Res., 39, 1215-1232, 2005.

Jørgensen, H., Jakobsen, K., and Eggum, B. O.: Determination of endogeous fat and fatty acids at the terminal ileum and on faeces in growing pigs, Acta Agr. Scand. A-An., 43, 101-106, 1993.

Keeling, C. D., Piper, S. C., Bacastow, R. B., Wahlen, M., Whorf, T. P., Heimann, M., and Meijer, H. A.: Atmospheric $\mathrm{CO}_{2}$ and ${ }^{13} \mathrm{CO}_{2}$ exchange with the terrestrial biosphere and oceans from 1978 to 2000: Observations and carbon cycle implications, in: A history of atmospheric $\mathrm{CO}_{2}$ and its effects on plants, animals, and ecosystems, Springer, New York, USA, 83-113, 2005.

Kind, J.: Ferromagnetic resonance spectroscopy and Holocene Earth's magnetic field variations in sediment from Swiss lakes, $\mathrm{PhD}$ thesis, ETH Zurich, Switzerland, 2012.

Kopp, J.: Veränderungen von Seen und Flussläufen in der Zentralschweiz in interglazialer und postglazialer Zeit, Mitteilungen der naturforschenden Gesellschaft Luzern, 19, 155-167, 1962. 
Lavrieux, M.: Biomarqueurs moléculaires d'occupation des sols, du sol au sédiment : exemple du bassin-versant et du lac d'Aydat (Puy-de-Dôme), PhD thesis, University Tours, France, 2011.

Lavrieux, M., Jacob, J., Le Milbeau, C., Zocatelli, R., Masuda, K., Bréheret, J. G., and Disnar, J. R.: Occurrence of triterpenyl acetates in soil and their potential as chemotaxonomical markers of Asteraceae, Org. Geochem., 42, 1315-1323, 2011.

Lehmann, M. F., Bernasconi, S. M., McKenzie, J. A., Barbieri, A., Simona, M., and Veronesi, M.: Seasonal variation of the $\delta^{13} \mathrm{C}$ and $\delta^{15} \mathrm{~N}$ of particulate and dissolved carbon and nitrogen in Lake Lugano: Constraints on biogeochemical cycling in a eutrophic lake, Limnol. Oceanogr., 49, 415-429, 2004.

Le Milbeau, C., Lavrieux, M., Jacob, J., Bréheret, J. G., Zocatelli, R., and Disnar, J. R.: Methoxy-serratenes in a soil under conifers and their potential use as biomarkers of Pinaceae, Org. Geochem., 55, 45-54, 2013.

Lichtfouse, E.: Heterogeneous turnover of molecular organic substances from crop soils as revealed by ${ }^{13} \mathrm{C}$ labeling at natural abundance with Zea mays, Naturwissenschaften, 84, 23-25, 1997.

Liess, M., Schulz, R., Berenzen, N., Nanko-Drees, J., and Wogram, J.: Pflanzenschutzmittelbelastung und Lebensgemeinschaften in Fliessgewässern mit landwirtschaftlich genutztem Umland, UBA Texte 65-01, Berlin, 227 pp., 2001.

Lohmann, F., Trendel, M. L., Hetru, C., and Albrecht, P.: C-29 tritiated $\beta$-amyrin: chemical synthesis aiming at the study of aromatization processes in sediments, J. Label. Compd. Radiopharm., 28, 377-386, 1990.

Lotter, A. F., Sturm, M., Teranes, J. L., and Wehrli, B.: Varve formation since 1885 and high-resolution varve analyses in hypertrophic Baldeggersee (Switzerland), Aquat. Sci., 59, 304-325, 1997.

Lotter, A. F.: The recent eutrophication of Baldeggersee (Switzerland) as assessed by fossil diatom assemblages, Holocene, 8, 395-405, 1998.

Lotter, A. F.: Pollen profile BALDEGG, Baldeggersee, Switzerland, European Pollen Database (EPD), https://doi.org/10.1594/PANGAEA.738987, 2010.

McCarroll, D., Gagen, M. H., Loader, N. J., Robertson, I., Anchukaitis, K. J., Los, S., Young, G. H. F., Jalkanen, R., Kirchhefer, A., and Waterhouse, J. S.: Correction of tree ring stable carbon isotope chronologies for changes in the carbon dioxide content of the atmosphere, Geochim. Cosmochim. Ac., 73, 15391547, 2009.

Makhutova, O. N., Borisova, E. V., Shulepina, S. P., Kolmakova, A. A., and Sushchik, N. N.: Fatty acid composition and content in chironomid species at various life stages dominating in a saline Siberian lake, Cont. Probl. Ecol., 10, 230-239, 2017.

Malaj, E., von der Ohe, P. C., Grote, M., Kühne, R., Mondy, C. P., Usseglio-Polatera, P., Brack, W., and Schäfer, R. B.: Organic chemicals jeopardize the health of freshwater ecosystems on the continental scale, P. Natl. A. Sci., 111, 9549-9554, 2014.

Marseille, F., Disnar, J. R., Guillet, B., and Noack, Y.: n-Alkanes and free fatty acids in humus and A1 horizons of soils under beech, spruce and grass in the Massif-Central (Mont-Lozère), France, Eur. J. Soil Sci., 50, 433-441, 1999.

Matthaei, C., Piggitt, J. J., and Townsend, C. R.: Multiple stressors in agricultural streams: interactions among sediment addi- tion, nutrient enrichment and water abstraction, J. Appl. Ecol., 47, 639-649, 2010.

Müller, B., Gächter, R., and Wüest, A.: Accelerated Water Quality Improvement during Oligotrophication in Peri-Alpine Lakes, Environ. Sci. Tech., 48, 6671-6677, 2014.

Müller, B., Meyer, J. S., and Gächter, R.: Alkalinity regulation in calcium carbonate-buffered lakes, Limnol. Oceanogr., 61, 341352, 2016.

Naeher, S., Niemann, H., Peterse, F., Smittenberg, R. H., Zigah, P. Z., and Schubert, C. J.: Tracing the methane cycle with lipid biomarkers in Lake Rotsee (Switzerland), Org. Geochem., 66, 174-181, 2014.

Neunlist, S., Rodier, C., and Llopiz, P.: Isotopic biogeochemistry of the lipids in recent sediments of Lake Bled (Slovenia) and Baldeggersee (Switzerland), Org. Geochem., 33, 1183-1195, 2002.

Niessen, F. and Sturm, M.: Die Sedimente des Baldeggersees (Schweiz) - Ablagerungsraum und Eutrophierungsentwicklung während der letzten 100 Jahre, Arch. Hydrobiol., 108, 365-383, 1987.

Otto, A. and Wilde, V.: Sesqui-, di-, and triterpenoids as chemosystematic markers in extant conifers - a review, Bot. Rev., 67, 141238, 2001.

Pancost, R., Baas, M., van Geel, B., and Sinninghe-Damste, J. S.: Biomarkers as proxies for plant inputs to peats: an example from a sub-boreal ombrotrophic bog, Org. Geochem, 33, 675-690, 2002.

Parker, P. L., Van Baalen, C., and Maurer, L.: Fatty acids in eleven species of blue-green algae: geochemical significance, Science, 155, 707-708, 1967.

Petrišič, M. G., Heath, E., and Ogrinc, N.: Lipid Biomarkers and Their Stable Carbon Isotopes in Oxic and Anoxic Sediments of Lake Bled (NW Slovenia), Geomicrobiol. J., 34, 606-617, 2017.

Popp, H.: Le siècle de la révolution agricole. L'agriculture et la politique agricole suisses au 20e siècle, Agri, Lausanne, Switzerland, 111 pp., 2001.

Reiffarth, D. G., Petticrew, E. L., Owens, P. N., and Lobb, D. A.: Sources of variability in fatty acid (FA) biomarkers in the application of compound-specific stable isotopes (CSSIs) to soil and sediment fingerprinting and tracing: A review, Sci. Total Environ., 565, 8-27, 2016.

Réveillé, V., Mansuy, L., Jardé, E., and Garnier-Sillam, E.: Characterisation of sewage sludge-derived organic matter: lipids and humic acids, Org. Geochem., 34, 615-627, 2003.

Rezbanyai, L.: Zur Insektenfauna des Siedereiteiches bei Hochdorf, Kanton Luzern, Entomologische Berichte Luzern, 5, 1-16, 1981.

Rubino, M., Etheridge, D., Trudinger, C., Allison, C., Battle, M., Langenfelds, R., Steele, L., Curran, M., Bender, M., and White, J.: A revised 1000 year atmospheric $\delta^{13} \mathrm{C}-\mathrm{CO}_{2}$ record from Law Dome and South Pole, Antarctica, J. Geophys. Res.-Atmos., 118, 8482-8499, 2013.

Scheurer, K., Alewell, C., Bänninger, D., and Burkhardt-Holm, P.: Climate and land-use changes affecting river sediment and brown trout in alpine countries - a review, Environ. Sci. Pollut. R., 16, 232-242, 2009.

Schindler Wildhaber, Y., Liechti, R., and Alewell, C.: Organic matter dynamics and stable isotope signature as tracers of the sources of suspended sediment, Biogeosciences, 9, 1985-1996, https://doi.org/10.5194/bg-9-1985-2012, 2012. 
Schouten, S., Klein Breteler, W. C. M., Blokker, P., Schogt, N., Rijpstra, I. C., Grice, K., Baas, M., and Damsté, J. S. S.: Biosynthetic effects on the stable carbon isotopic compositions of algal lipids: Implications for deciphering the carbon isotopic biomarker record, Geochim. Cosmochim. Ac., 62, 1397-1406, 1998.

Simoneit, B. R. T.: Cyclic terpenoids of the geosphere, in: Biological markers in the Sedimentary Record, Johns, R.B. Elsevier, Amsterdam, Netherlands, 43-100, 1986.

Six, J. and Jastrow, J.: Organic Matter Turnover, Encyclopedia of Soil Science, https://doi.org/10.1201/NOE0849338304.ch252, 2002.

Stadelmann, P., Lovas, R., and Butscher, E.: 20 Jahre Sanierung und Überwachung des Baldeggersees, Mitteilungen der Naturforschenden Gesellschaft Luzern, 37, 113-164, 2002.

Stefanova, M., Oros, D. R., Otto, A., and Simoneit, B. R. T.: Polar aromatic biomarkers in the Miocene Maritza-East lignite, Bulgaria, Org. Geochem., 33, 1079-1091, 2002.

Summons, R. E., Jahnke, L. L., and Roksandic, Z.: Carbon isotopic fractionation in lipids from methanotrophic bacteria: Relevance for interpretation of the geochemical record of biomarkers, Geochim. Cosmochim. Ac., 58, 2853-2863, 1994.

Sundermann, A., Gerhardt, M., Kappes, H., and Haase, P.: Stressor priorisation in riverine ecosystems: Which environmental factors shape benthic invertebrate assemblage metrics?, Ecol. Indic., 27, 83-96, 2013.

Teranes, J. L. and Bernasconi, S. M.: Factors controlling $\delta^{13} \mathrm{C}$ values of sedimentary carbon in hypertrophic Baldeggersee, Switzerland, and implications for interpreting isotope excursions in lake sedimentary records, Limnol. Oceanogr., 50, 914-922, 2005.

Tolosa, I., Fiorini, S., Gasser, B., Martín, J., and Miquel, J. C.: Carbon sources in suspended particles and surface sediments from the Beaufort Sea revealed by molecular lipid biomarkers and compound-specific isotope analysis, Biogeosciences, 10, 20612087, https://doi.org/10.5194/bg-10-2061-2013, 2013.

US EPA: National Water Quality Inventory: Report to Congress 2004, Reporting Cycle January 2009, United States Environmental Protection Agency Office of Water Washington, DC 20460 EPA 841-R-08-001, 2009.

van Bree, L. G. J., Peterse, F., van der Meer, M. T. J., Middelburg, J. J., Negash, A. M. D., De Crop, W., Cocquyt, C., Wieringa, J. J., Verschuren, D., and Sinninghe Damsté, J. S.: Seasonal variability in the abundance and stable carbon-isotopic composition of lipid biomarkers in suspended particulate matter from a stratified equatorial lake (Lake Chala, Kenya/Tanzania): Implications for the sedimentary record, Quat. Sci. Rev., 192, 208-224, 2018.

van der Knaap, W. O., van Leeuwen, J. F. N., Fankhauser, A., and Ammann, B.: Palynostratigraphy of the last centuries in Switzerland based on 23 lake and mire deposits: chronostratigraphic pollen markers, regional patterns, and local histories, Rev. Palaeobot. Palyno., 108, 85-142, 2000.

van Raden, U.: High resolution Swiss lake records of climate change, PhD Thesis, ETH Zurich (Switzerland), 2012.
Verburg, P.: The need to correct for the Suess effect in the application of $\delta^{13} \mathrm{C}$ in sediment of autotrophic Lake Tanganyika, as a productivity proxy in the Anthropocene, J. Paleolimnol., 37, 591-602, 2007.

Volkman, J. K., Burton, H. R., Everitt, D. A., and Allen, D. I.: Pigment and lipid compositions of algal and bacterial communities in Ace Lake, Vestfold Hills, Antarctica, Hydrobiologia, 165, 4157, 1988.

Volkman, J. K., Barrett, S. M., Blackburn, S. I., Mansour, M. P., Sikes, E. L., and Gelin, F.: Microalgal biomarkers: A review of recent research developments, Org. Geochem., 29, 1163-1179, 1998.

Wakeham, S. G., Schaffner, C., and Giger, W.: Polycyclic aromatic hydrocarbons in Recent lake sediments - II. Compounds derived from biogenic precursorsduring early diagenesis, Geochim. Cosmochim. Ac., 44, 415-429, 1980.

Wakeham, S. G. and Canuel, E. A.: Biogenic polycyclic aromatic hydrocarbons in sediments of the San Joaquin River in California (USA), and current paradigms on their formation, Environ. Sci. Pollut. R., 23, 10426-10442, 2016.

Wasson, J., Villeneuve, B., Iital, A., Murray-Bligh, J., Dobiasova, M., Bacikova, S., Timm, H., Pella, H., Mengin, N., and Chandesris, A.: Large-scale relationships between basin and riparian land cover and the ecological status of European rivers, Freshwater Biol., 55, 1465-1482, 2010.

Wehrli, B., Lotter, A. F., Schaller, T., and Sturm, M.: Highresolution varve studies in Baldeggersee (Switzerland): Project overview and limnological background data, Aquat. Sci., 59, 285-294, 1997.

Whiticar, M. J.: Carbon and hydrogen isotope systematics of bacterial formation and oxidation of methane, Chem. Geol., 161, 291314, 1999.

Wiesenberg, G. L. B.: Input and turnover of plant-derived lipids in arable soils, $\mathrm{PhD}$ thesis, University Cologne, Germany, 2004.

Wiesenberg, G. L. B., Schwarzbauer, J., Schmidt, M. W. I., and Schwark, L.: Source and turnover of organic matter in agricultural soils derived from $n$-alkane/ $n$-carboxylic acid compositions and C-isotope signatures, Org. Geochem., 35, 1371-1393, 2004.

Wiesenberg, G. L. B., Schwarzbauer, J., Schmidt, M. W. I., and Schwark, L.: Plant and soil lipid modification under elevated atmospheric $\mathrm{CO}_{2}$ conditions: II. Stable carbon isotopic values $\left(\delta^{13} \mathrm{C}\right)$ and turnover, Org. Geochem., 39, 103-117, 2008.

Yunker, M. B. and MacDonald, R. W.: Composition and origins of polycyclic aromatic hydrocarbons in the Mackenzie River and on the Beaufort Sea shelf, Arctic, 48, 118-129, 1995.

Yunker, M. B. and MacDonald, R. W.: Alkane and PAH depositional history, sources and fluxes in sediments from the Fraser river basin and strait of Georgia, Canada, Org. Geochem., 34, 1429-1454, 2003.

Zhao, F. J., Spiro, B., and McGrath, S. P.: Trends in ${ }^{13} \mathrm{C} /{ }^{12} \mathrm{C}$ ratios and $\mathrm{C}$ isotope discrimination of wheat since 1845 , Oecologia, 128, 336-342, 2001. 